\title{
INFLUENCE OF THE GLOBAL FINANCIAL CRISIS ON THE SEPARATIST ASPIRATIONS OF CATALONIA FROM THE PERSPECTIVE OF SPANISH INTERNAL LAW
}

\section{Michał Zbigniew Dankowski*}

Abstract: The Catalan Crisis of 2017-2018 has shown significant misunderstandings in the internal legal system of Spain. Many issues of the legal system were differently understood by the central government and by the autonomous authorities in Barcelona. It concerned such as important issues like the institution of referendum, which was interpreted differently by politicians from Madrid and the Constitutional Court and otherwise by those from Barcelona. The genesis of the constitutional crisis itself is rooted in the global economic crisis that began in the second half of the last decade, as it was then that the Catalan nationalist movement radicalized.

Key Words: Spain, Catalonia, constitutional crisis, economic crisis, Constitutional Court

\section{Financial crisis in Spain}

The global financial crisis, which dates back to 2008, hit the Spanish economy particularly hard. Earlier, the fourth largest economy of the euro

* Michał Zbigniew Dankowski, Kolegium Jagiellońskie, Toruń 
area $^{1}$ fell into depression and recession. Projected GDP growth for 2008 was $3.1 \%$, while the actual growth made only $1.1 \%$. The following year was even worse due to the fact that it brought GDP down by 3.6\%. A brief respite occurred in 2010, when GDP at the end of the year remained at the same level as at the beginning of the year. However, over the next three years, the Spanish economy recorded a recession of $1 \%, 2.9 \%$ and $1.7 \%$, respectively, finally escaping the crisis in 2014, when GDP began growing again $^{2}$. As a result of the collapse of the global financial system, the most important sectors of the Spanish economy suffered, among them especially construction, banking, services and industry.

The greatest consequences have been on the real estate market, due to the so-called real estate bubble, that is the disproportionate increase in prices of new apartments in relation to inflation from the mid-1990s. The reason for the above were several parallel factors, among which the most important were a land development deficit for residential housing, tax breaks associated with the purchase of real estate, an increase of immigration, change of land properties classifications, speculation and, above all, an almost uncontrolled increase in housing loans granted by banks ${ }^{3}$.

The situation in the real estate market caused the banking crisis, which peaked in 2010, which in turn caused a significant increase in unemployment in Spain. As a consequence, numerous social movements arose (the largest being Movement 15-M, Movimiento 15-M), which aimed at changing the economic and production model of the state, and consequently they postulated changes in the political system.

The PSOE (Partido Socialista Obrero Español) socialist government at the time, headed by José Luis Rodríguez Zapatero, tried to fight the crisis by reducing state job offers and freezing wages for the highest state jobs (mid-2008). The bankruptcy of the construction company Martinsa-Fadesa resulted in the bankruptcy of Caja Madrid bank, the main creditor

1 C. Pérez, La crisis en España: cronología desde 2008, http://www.rtve.es/ noticias/20120605/crisis-espana-cronologia-desde-2008/533400.shtml (accessed 1.12.2017).

2 Data from the Spanish National Institute of Statistics: http://www.ine.es/prensa/ pib_tabla_cne.htm (accessed 1.12.2017).

3 G. Bernardos Domínguez, Creación y destrucción de la burbuja inmobiliaria en España, "Información Comercial Española. Revista de Economía" 2009, no 850, at p. 24-25; A.R. Fernández Rincón, E. Trindade, P.A. Hellín Ortuño, Comprender la burbuja inmobiliaria en España, "Revista Brasileira de Ciências Sociais" 2015, vol. 32, no 95. 
of the developer which caused an avalanche of subsequent bankruptcies, as well as the start of the global crisis in October 2008, marked by the collapse of numerous US banks. The Zapatero government then presented Plan E (Plan Español, el el Estímulo de la Economía y el Empleo), a Spanish plan of economic and employee stimulation. It assumed the introduction of 82 reforms in the financial sector, the most important of which were: the establishment of the National Fund for Local Investments (Fondo Estatal de Iversion Local), the aim of which was to co-finance the most urgent public works at the municipal level; the establishment of the National Fund for Economic Development and Employment (Fondo Nacional de Dinamización de la Economía y el Empleo) and the reduction of current expenditure in the state budget for 2009. The plan did not bring the expected results, and its introduction proved expensive, in some cases exceeding the planned income ${ }^{4}$.

In view of the growing crisis in the banking sector, in mid-2009 the government established the Fund for the Orderly Ordered Banking Restructuring (Fondo de Reestructuración Ordenada Bancaria, FROB) ${ }^{5}$. In the face of the next stage of the economic crisis in 2011, the Constitution was reformed. Article 135, which so far provided the government with the authority to incur public debt, was broadened essentially, expressing the principle of "budgetary stability" (estabilidad presupuestaria). The largest Spanish parties, the ruling socialist PSOE and the opposition center-right Partido Popular (PP), decided to implement the reform. The basic assumption of the principle of fiscal stability was the ban on exceeding the previously determined deficit by the European Union, both by the central government and by the governments of autonomous communities.

In November 2011, the opposition center-right PP won the general election. The victorious party proceeded to find countermeasures against the economic crisis. Cuts in the public sector were carried out by reducing enterprises and state positions, as well as by increasing VAT rates. A reform of labour law (including the limitation of additional wages paid at the end of the year employed in the public sector, reduction of days off for personal affairs), and the implementation of the recovery plan (rescate) imposed by the European Union, consisting of government subsidies for using FROBs threatened by the collapse of banks were carried out. Spanish society was

4 L. Doncel, Mucho empleo, pero poco productivo, "El País", 30.08.2009: https://elpais. com/diario/2009/08/30/economia/1251583202_850215.html (accessed 6.12.2017).

5 Real Decreto-Ley 9/2009, BOE, no 155, 27.6.2009. 
severely affected due to further budget cuts and increased VAT rates. In July 2012, some of the autonomous communities, including Catalonia, also needed government funding. This fact contradicts the propaganda promoted by the autonomous government, which as one of the arguments in favour of detachment from the rest of the state, gives an obligation to maintain the rest of the state by Catalonia.

The rescue methods introduced by the Rajoy government have brought the expected results. At the end of 2013, the Prime Minister assured people that the plan had been implemented and the following year would see an upturn. At the same time, in view of the increased activity of the separatist movement in Catalonia, Rajoy admitted that he was open to dialogue with everyone, but he did not agree to any division of Spain ${ }^{6}$.

\section{Intensification of political activity of Catalan separatists}

In addition to the severity of economic affairs, the crisis has had a special impact on Spain, due to the characteristics of its political and administrative system. The Kingdom of Spain under the Constitution of 1978 is a unitary state, which however, consists of 17 regions with highly developed political independence, the so-called autonomous communities (comunidades autónomas). In some autonomous communities there are strong centrifugal movements, aimed at widening their autonomy, which is already the widest in Europe, and even to detach from Spain and create an independent state. The most separatist-oriented regions are the Basque Country and Catalonia.

Even the adoption in 2006 of a new autonomous statute for Catalonia, which further extended the autonomy of the community, did not stop some politicians in their drive for full emancipation from the state structures of Spain. The slogans of the Catalan nationalists coincided with the start of the economic crisis in 2008 and became one of the most frequent arguments for the Catalan community in the cause of independence. Willingly the proportion of Gross Domestic Product was pleaded, where Catalonia invariably exceeds $18 \%$ on the national scale for years, remaining

6 C.E. Cué, Rajoy confía en salir del pozo en 2014, “El País”, 27.12.2013: https:// politica.elpais.com/politica/2013/12/27/actualidad/1388148826_283231.html (accessed 6.12.2017). 
a leader among the autonomous communities ${ }^{7}$. Catalan economists also calculate that taxes, which are paid into the state coffers, amounted to over EUR 13 billion per year, were not returned to the region, and spent on other, poorer parts of Spain ${ }^{8}$.

Catalan nationalists used these statistics, which were useful for their propaganda. Analyzing the economic situation of the region in this period, it should be noted that in 2009, the decline in Catalonia's GDP was $4.1 \%$, placing it among the four autonomous communities with the worst economic result at the end of the year. At the end of 2010, together with the Valencian Community, Catalonia was among the most indebted Autonomous Communities?.

Despite the negative economic results of the region, Catalan nationalists looked to the stereotype of rich Catalonia and poor Castile and advocated the continued need for allegedly maintaining the poorer regions of Spain. Catalonia as one of the three so-called "historical nationalities" (alongside the Basque Country and Galicia) has somewhat broader autonomous competences than other communities. In particular, this concerns the issue of establishing and collecting taxes. The situation meant that the economic crisis had different consequences for autonomous communities depending on the scope of their autonomy in the field of public finances.

The Basque Country has the widest competences in public finances, which caused dissatisfaction among Catalan politicians. Since the new statute was adopted, successive governments of Catalonia had been trying to force the central government to introduce the so-called pacto fiscal, similar to the Basque Country. Under the fiscal pact, all competences related to public finances, which until now had been the responsibility of state authorities, would be ceded to autonomous institutions ${ }^{10}$.

7 Catalunya aporta más que la Comunidad de Madrid al PIB español, "La Vanguardia”, 9.9.2016, http://www.lavanguardia.com/economia/20160909/41203304522/catalunyamadrid-pib-espana.html (accessed 30.7.2017).

8 F.M. Álvaro, S. Cardús (ed.), Claves sobre la independencia de Cataluña, Barcelona 2013, at p. 75 .

9 A. Bolaños, La deuda de las comunidades supera por primera vez el 10\% del PIB, "El País”, 18.12.2010. https://elpais.com/diario/2010/12/18/economia/1292626805_850215. html (accessed 6.12.2017).

10 Coca M.T., A qué aspira Cataluña con el pacto fiscal, “El Mundo”, 20.9.2012: http:// www.elmundo.es/elmundo/2012/09/19/barcelona/1348077306.html (accessed 30.7.2017). 
The head of the Spanish government, Mariano Rajoy, consistently rejected the possibility of negotiating any concession to Catalonia in this regard, believing that a precedent would entail more autonomous communities and hence the complete financial decentralization of the state ${ }^{11}$.

Catalan researchers dealing with the issue of correlation between economics, law and separatist moods indicate unequivocally that apart from the financial crisis, repealing the most controversial regulations of the new autonomous statute of 2006 by the Constitutional Court based on the judgment issued in 2010, had the greatest impact on strengthening the independence positions in Catalonia ${ }^{12}$.

Until the autonomous Statute was adopted in 2006, the political autonomy of the region, governed by the Statute of 1979, was narrower than in regions in federal states such as German federal states or the North American states ${ }^{13}$. The new Statute provides for the further extension of the autonomy of the region, although it still remains a compromise developed between Madrid and Barcelona politicians. The original version adopted by the Catalan Parliament assumed, among others, elevation of the Catalan language over Castilian in public administration, changes in the financial system of Catalonia through the establishment of the Catalan banking system, the possibility of establishing separate taxes in the autonomous community, and above all, reducing the contribution to the state budget, and conducting its own migration policy and sovereignty in conducting political consultations and referendums. All the above controversial regulations were found unconstitutional by the Constitutional Court. Above all, the new autonomous Statute contains wording that the Catalan Parliament defined Catalonia as a nation (nación), while the Constitution recognizes the identity of Catalonia by the concept of nationality (nacionalidad), which occurred in the previously existing

11 García L.B., Rajoy rechaza un concierto fiscal y un nuevo Estatut pero ofrece "más inversiones", “La Vanguardia", 26/01/2017. http://www.economiadigital.es/ politica-y-sociedad/rajoy-rechaza-el-pacto-fiscal-con-cataluna-para-no-romperespana_188601_102.html (accessed 30.7.2017).

12 G. Rico, R. Liñeira, Bringing Secessionism into the Mainstream: The 2012 Regional Election in Catalonia, "South European Society and Politics" 2014, vol. 19, no 2, at p. 258.

13 A. Balcells, Breve historia del nacionalismo catalán, Madrid 2004, at p. 9. The specific political model of modern Spain is discussed in more detail by A. Sroka, Hiszpańska droga do federalizmu [The Spanish way to federalism], Wrocław 2008. 
autonomous Statute of $1979^{14}$. The project itself had the concept of Catalan nation, which, however, was considered unconstitutional by Madrid, because it caused a specific national duality, accentuating the difference between the Spanish and Catalan people, which according to the Constitution, does not exist, because the basic law mentions only one nation: Spanish. This one consists of various nationalities, including Catalan. The Catalan Parliament in its statement of reasons recognized that the term nación and nacionalidad are "identical and interchangeable" and do not infringe the existing Article 2 of the Constitution. At the same time, it was stressed that Article 147.2.a of the Constitution provides that each autonomous community may indicate in its autonomous Statute a "nomenclature that best corresponds to its historical identity." ${ }^{15}$ However, in 2010 the Constitutional Court recognized the ineffectiveness of the regulation of the Catalan nation mentioned in the preamble of the autonomous Statute ${ }^{16}$.

The Catalan politicians decided to appeal to the institutions of direct democracy in order to implement their plans related to the independence of the region. When looking for arguments of a legal nature, they referred to Article 92.1 of the Constitution, which states: "Political decisions of special significance may be subject to a referendum consulting all citizens" and to the Organic Law 2/1980, where it distinguishes, among others, an autonomous consultative referendum (referéndum consultivo autonómico), which requires the prior authorization of the central authorities ${ }^{17}$. The Constitutional Court rejected the possibility of referring to direct democracy in matters related to the identity and unity of interested

14 Ley Orgánica 6/2006, de 19.7.2006, de reforma del Estatuto de Autonomía de Cataluña, BOE, no 172, 20.7.2006, Preamble.

15 J. Garriga, Cuatro obstáculos para el nuevo Estatuto, “El País”, 1.10.2005: https:// elpais.com/diario/2005/10/01/espana/1128117609_850215.html (accessed 17.7.2017). Art. 147.2.a CE.

16 The Statute itself was found to be in conformity with the Constitution in essence, with the exception of 14 articles, as well as the submission of 27 other articles of reinterpretation according to the interpretation of the Constitutional Court, but unanimously (votes 6:4). According to the verdict, the preamble cannot be treated as a source of law. Sentencia del Tribunal Constitucional (further: STC) 31/2010, 28.6.2010; BOE, no 172, 16.7.2010.

17 Ley orgánica 2/1980, de 18.1.1980, sobre regulación de las distintas modalidades de referéndum, BOE, no 20, 23.1.1980. More on the subject of direct democracy institutions in Spain, see: M. Llorens Ferrer, La consulta popular como mecanismo para revitalizar el urbanisto democrático, "Revista catalana de dret públic" 2013, no 46, at p. 164-167. 
entities $^{18}$. Therefore, it was not possible to conduct a binding referendum exclusively in Catalonia in the light of the regulations in force. Such an initiative could, however, take place if all eligible citizens of Spain took part in it or if the government in Madrid had transferred the competence to hold a referendum to the regional government in Barcelona pursuant to Article 150.2 of the Constitution. It would be possible by adopting an organic law (Ley orgánica) with the absolute majority of both chambers of the general parliament. In the Spanish political system, where two political parties, PSOE and PP, have ruled since the return of democracy and both strongly oppose any negotiations on secession, this seems unlikely.

In view of the limited constitutional basis for holding a referendum on independence, the Catalan parliament adopted Act $4 / 2010^{19}$ authorizing public consultations (consulta popular). The new institution was to apply to questions about important political issues and to be exclusively applied within the autonomous community. The legal structure used by the Government of Catalonia (Generalitat) allows the carrying out of consultations that have the characteristics of a referendum only among Catalans without the participation of state authorities in the process which would only authorize the final results of the vote ${ }^{20}$. Again, however, the Constitutional Court upheld the distinction of public consultations and a referendum, declaring that the referendum lies within the exclusive competence of state authorities, not autonomous ones ${ }^{21}$.

18 An exception is constitutional reform through a referendum. STC 103/2008, de 11.9.2008, BOE, no 245, 10.10.2008.

19 Ley 4/2010, de 17.3.2010, de consultas populares por vía de referéndum, BOE, no 93, 17.4.2010.

20 E. Martín Núñez, The referendum and popular consultations in the Autonomous State, "Perspective on Federalism" 2012, vol. 4, no 1, , at p. 145 et seq.

21 STC 31/2010, de 28.6.2010, BOE, no 172, 16.72010. It should be noted that public consultations are also carried out in other autonomous communities. However, they concern only issues related to matters within the competence of the authorities of autonomous communities. In addition, the essential differences between the referendum and public consultations are: persons entitled to vote (in the case of public consultations also persons from 16 years of age, as well as foreign residents), using the state register of voters in the case of a referendum and registration of participation according to regional data for public consultations. Public consultations do not require the consent of the government and they do not have a guarantee of state electoral commissions (juntas electorales), but only a control committee (Comisión de Control). See: M. Barceló, Diferencias entre un Referéndum y una Consulta, "El Diario", 23.9.2014: http://www.eldiario.es/agendapublica/ 
Finally, the Catalonian Government, unable to legally call a referendum on independence, decided to use the Article 122 of the autonomous Statute of Catalonia on public consultations as a legal basis for holding a voting in the spirit of direct democracy. The above-mentioned regulation states that Generalitat has exclusive competence to convene social consultations, with the exception of the one mentioned in Article 149.1.32 of the Constitution, which is, authorizing public consultations by means of a referendum.

\section{Impact of Spanish government economic policy on social mood in Catalonia}

The secession policy pursued by the Catalan Government received broad public support. However, it was not the government's actions that became the main factor influencing separatist moods, but the economic situation of the region, in particular the drastic increase in unemployment. After all in 2010, politicians of the convergent coalition Convergencia and Unió ( $\mathrm{CiU}$ ) during the election campaign to the autonomous parliament promised that financial restraint and cuts in the budget would bring the crisis under control. After winning the elections, $\mathrm{CiU}$ agreed with the new central government, which on behalf of the PP, began cuts in the autonomous budget ${ }^{22}$. Returning to power in Catalonia after seven years, $\mathrm{CiU}$ faced a great challenge to overcome the economic crisis. Sensing the public mood, the extreme nationalist wing of the ruling coalition (Convergència Democràtica de Catalunya, $C D C$ ) decided to take advantage of the crisis for greater autonomy, and perhaps even political independence from Madrid.

According to a report realized by the Generalitat, along with the increase in unemployment in the region, support for the independence of Catalonia grew, reaching about 50\% at its peak in 2012, while every fourth inhabitant of the region remained unemployed ${ }^{23}$. It was then that,

reforma-constitucional/Diferencias-Referendum-Consulta_0_306220129.html (accessed 23.7.2017).

22 J.C. Díez, La relación entre la economía y el independetismo catalán, "Crónica Global”, 8.9.2017: https://cronicaglobal.elespanol.com/business/relacion-economiaindependentismo_86045_102.html (accessed 4.12.2017).

${ }^{23}$ Data of the Catalan Center for Opinion Studies (Centre d'Estudis d'Opinió): http:// ceo.gencat.cat/ceop/AppJava/pages/index.html (accessed 1.12.2017). 
after the cuts in 2012 and the implementation of the recovery plan (rescate), primarily in the health and education sectors, that Catalan society became disappointed with the central government, feeling strongly imposed state control and the inability to influence regional financial policy.

The Catalan Parliament and the autonomous government consistently carried out activities aimed at secession. After the elections at the end of 2012, a declaration of sovereignty was adopted, meaning, according to the project promoters, that Catalan society has sovereign political and legal subjectivity ${ }^{24}$. Subsequently, the Catalan Parliament recognized that it had the right to "carry out a bilateral dialogue with the central government" ${ }^{25}$, which would be tantamount to recognizing the Catalan side as equal to the national authorities of Spain. Of course, both acts were first suspended by the Constitutional Court and then declared unconstitutional and invalid (inconstitucional y nula). The justification of the verdict stated that an "Autonomous Community cannot unilaterally call a referendum on self-determination, which would decide on its integration with Spain"26. This did not change the proceedings of Generalitat, which was preparing to organize public consultations on independence.

In 2013, the European Commission approved the request of Prime Minister Rajoy and decided to give Spain a little more time to reach its deficit goals, and thus begin on the path of recovering from recession, which ultimately brought the desired result the following year. With the return of economic growth, public support for separatism began to gradually decline in Catalonia. In 2015, the European Central Bank began a public debt financing program through the purchase of government bonds, including Spain, similar to what the North American Federal Reserve System initiated five years earlier. The effects of such action were immediate throughout Spain, also in Catalonia. At the time, unemployment in the region decreased by $3.5 \%$, which caused another decline in public support for the idea

24 M. Colomer, La declaració de sobirania ja fa via al Parlament, “Ara”, 22.1.2013: http:// www.ara.cat/politica/declaracio-sobirania-Parlament-CiU-ERC-ICV_0_851914901.html (accessed 23.7.2017).

25 Resolució 17/X del Parlament de Catalunya, sobre la iniciació d'un diàleg amb el Govern de l'Estat per a fer possible la celebració d'una consulta sobre el futur de Catalunya: https://www.parlament.cat/document/actualitat/150210.pdf (accessed 4.10.2017).

26 "Una Comunidad Autónoma no puede unilateralmente convocar un referéndum de autodeterminación para decidir sobre su integración en España" (translated by the author). STC 42/2014, 25.3.2014, BOE, no 87, 10.4.2014. 
of independence. The existing situation indicates how strong correlation exists between the state of the region's economy and social support for independence.

Nevertheless, the nationalists in power in Catalonia have gone too far in their separatist policy to make it possible to retreat from their chosen path, without the risk of losing credibility and political support. In this situation, the continuation of the independence policy has become a priority for the Catalan government, pushing other issues to the background. What is more, in the face of overcoming the economic crisis and, consequently, the decline in support for the separatist idea in the society, Generalitat pushed for independence in an express mode to take advantage of the favorable economic situation generated mainly due to economic propaganda.

\section{Two Catalan referendums (2014 and 2017)}

Meanwhile, at the beginning of 2014, the Catalan Parliament once again tried to initiate a referendum procedure through constitutional legalism and requested the Congress of Deputies (lower house of the Spanish parliament) regarding the transfer of powers to carry out a referendum on autonomous community authorities in accordance with Article 150.2 of the Constitution. The Congress of Deputies rejected by a large majority (299:47) the request of the Catalans ${ }^{27}$. In September 2014, the Catalan Parliament passed a "law on non-referendum public consultations and other forms of civic participation" ${ }^{28}$. The day after the publication of the Act in the information bulletin of the Catalan Parliament (27 September 2014), the independence consultation was announced on 9 November, this year.

27 Boletín Oficial de las Cortes Generales (further: BOCG), Congreso de los Diputados, serie B, núm. 158-1, de 24.1.2014; BOCG, Congresdo de los Diputados, serie B, no 158-2, 11.4.2014. It is interesting to note that other regional nationalist parties (from the Basque Country, Navarra and Galicia) represented in the parliament voted for the petition of the Generalitat. More on regional parties in Spain, see: M. Myśliwiec, Pozycja partii regionalnych $w$ systemie politycznym wspótczesnej Hiszpanii [Position of regional parties in the political system of contemporary Spain], Katowice 2014.

28 Ley 10/2014, 26.9.2014, de consultas populares no referendarias y otras formas de participación ciudadana, BOE no 64, 16.3.2015. More on the referendums in Catalonia, see: M.Z. Dankowski, The legality of Catalan independence referendums, "Przegląd Prawa Konstytucyjnego" 2017, no 6, at p. 87-100. 
In response, the central government appealed Catalan law on consultations to the Constitutional Court, which in effect suspended two articles of this act, the contents of which granted the Generalitat the opportunity to organize public consultations. Finally, in February 2015, the Constitutional Tribunal unanimously ruled on the unconstitutionality of the suspended norms, noting that in fact under the term "non-referendum public consultations" there is a referendum reserved exclusively for the central government ${ }^{29}$.

The non-legal plebiscite ultimately took place under the name of the "process of civic participation on the political future of Catalonia"30. Due to the inability to use official electoral lists, the turnout remained difficult to estimate accurately. Over 2.3 million people took part in the vote (which is slightly less than $40 \%$ of those entitled to participate in the consultation ${ }^{31}$ ). The supporters of separatism certainly won, reaching slightly more than $80 \%$ of positive votes. Faced with such overwhelming supremacy, the then head of the Catalan government Arturo Mas assured the people that he would strive to organize a final and legal referendum. Meanwhile, the General Prosecutor brought charges against the presidents of the Catalan government (Mas and his deputy Joan Ortega and Education Adviser Irene Rigau) for disobedience to the state and embezzlement of public funds ${ }^{32}$. In March 2017, all were convicted by the Superior Court of Justice of Catalonia (Tribunal Superior de Justicia de Cataluña) in accordance with Article 410 of the Criminal Code (Código Penal) for the ban on holding public functions and a fine ${ }^{33}$.

Measures for the secession of Generalitat were intensified after the regional elections of 2015. The victorious coalition of independence

29 STC 32/2015, 25.2.2015, BOE no 64, 16.3.2015.

30 Procés de participació ciutadana sobre el futur polític de Catalunya (translated by the author).

${ }^{31}$ It is estimated that about 6.3 million people were entitled to vote, of which 5.4 million from official state electoral lists, 0.77 million foreigners with resident status and 0.13 million underage persons allowed to vote (16-17 year-olds): http://www.gesop. net/images/pdf/ca/BREUS\%20DE\%20DADES/22.\%20BreuDades_9NProcesParticipatiu. pdf (accessed 23.7.2017).

32 R. Rincón, M. Fabra, La cúpula fiscal avala a Torres-Dulce en la querella contra Mas por el 9-N, “El País”, 19.11.2014: https://politica.elpais.com/politica/2014/11/19/ actualidad/1416388068_261754.html (accessed 24.7.2017).

33 Text of the judgment: http://www.elperiodico.com/es/politica/20170313/textointegro-fallo-sentencia-9n-5893943 (accessed 24.7.2017). Mas was no longer the head of the government at that time because he resigned from this function in January 2016. 
radical groups Juns Pel Sí $(\mathrm{JxS})^{34}$, which entered into a coalition with another separatist group Candidatura de Unidad Popular (CUP), gave them a majority in the Parliament of Catalonia. During the first session after the elections, the Parliament of Catalonia adopted a resolution on the issue of the formal start of the process to create an independent Catalan state ${ }^{35}$. In response, the government in Madrid filed a complaint to the resolution with the Constitutional Court, which overturned it, considering it incompatible with the principle enshrined in Article 2 of the Constitution on the "indivisibility of the Spanish nation"36. The Parliament of Catalonia predicted a similar judgment of the Court because the resolution contains a regulation calling on the regional government to disregard unfavorable judgments of the Constitutional Court to the cause of independence ${ }^{37}$. This situation revealed completely the confrontational attitude of the ruling politicians in Catalonia who did not intend to give way. In 2017 the situation became critical, and it appeared obvious that both sides would not withdraw from their positions. Public law became a tool for achieving political goals, ceasing to be a guarantor of state stability.

The next referendum was scheduled for 1.10.2017. Carles Puigdemont, the head of the Catalonian government, did not give in to the threats

34 The coalition was formed after the collapse of the previous coalition, the $\mathrm{CiU}$ which included two parties: the liberal-center-right CDC and the Christian Democratsica de Catalunya (UDC), which has won the Catalan parliament elections continuously since the first elections from 1980 (excluding 2003 and 2006, when the government was formed by a coalition of Catalan left-wing parties), until its dissolution in 2015. The breakdown of $\mathrm{CiU}$ took place due to differences in views of both groups on independence issues. The CDC pushed for independence regardless of the position of the central government and legal aspects, while the UDC proposed an independence path consistent with the letter of applicable law. Afterwards CDC united other radically nationalist Catalan parties: the Pancatán Esquerra Republicana de Catalunya (ERC), Christian Democratic Demòcratas de Catalunya, formed after the split in the UDC, bringing together its radically independent members and the Social Democratic Moviment d'Esquerres. For more on the policy pursued by $\mathrm{CiU}$ before the 2006 reform of the autonomous statute see: M. Myśliwiec, Katalonia na drodze do niepodległości? [Catalonia on its way to independence?], Bytom 2006, at pp. 50-80, and on the first coalition government of the Catalan leftist parties see: V. Villatoro, Catalunya després del Tripartit. Una visió nacionalista, Columna, Barcelona 2005.

35 Resolució 1/XI del Parlament de Catalunya, sobre l'inici del procés polític a Catalunya com a conseqüència dels resultats electorals del 27.9.2015, Butlletí Oficial del Parlamento de Catalunya no 7, 9.11.2015.

36 STC 259/2015, 2.12.2015, BOE, no 10, 12.1.2016.

37 Resolució $1 / \mathrm{XI}$..., sec. 6. 
of force from the Spanish government and instigated a referendum. It was, as previously announced, unlike the referendum in 2014 because it had the support of the strong political and social majority of Catalonia ${ }^{38}$. The policy of Generalitat was legalized by the act of the Catalan autonomous parliament adopted on 6 September 2017, which allowed a referendum on self-determination ${ }^{39}$. At the request of Prime Minister Rajoy, the Constitutional Court urgently suspended the validity of the Catalan law on referendum ${ }^{40}$. The Catalans officially admitted that they would ignore the decisions of the Constitutional Court unfavorable to their case ${ }^{41}$.

Rajoy's government remained relatively passive on the insubordinate actions of the Catalans. It did not react strongly in any preventive way, limiting itself to filing complaints to the Constitutional Court regarding subsequent legal acts passed by the Catalan parliament, which undermined the principle of the territorial integrity of the state and disturbed the constitutional order, disrupting the supremacy of the central government towards the autonomous community organs. Obviously, the Constitutional Court considered all manifestations of Catalan separatism expressed in acts adopted by the autonomous parliament as incompatible with the Constitution.

Only the actual preparations for organizing the next referendum, declared illegal by the Constitutional Court, caused a reaction in the central government, which sent order forces to prevent the planned public consultations. On the day of the planned referendum, the current political conflict between Madrid and Barcelona turned into a large riot involving the uniformed services and Catalan civilians. The state services intervened in the polling stations, in line with the government's guidelines, to prevent

38 El president Puigdemont, el vicepresident Junqueras i el conseller Romeva explicaran al Parlament Europeu el referèndum que Catalunya celebrarà aquest 2017 of 19.1.2017: http://premsa.gencat.cat/pres_fsvp/AppJava/convocatoriavw/132559/ca/presidentpuigdemont-vicepresident-junqueras-conseller-romeva-explicaran-parlament-europeureferendum-catalunya-celebrara-2017.do (accessed 30.7.2017).

39 Ley 19/2017, 6.9.2017, del referèndum de autodeterminación, Diari Oficial de la Generalitat de Catalunya (further: DOGC), N. 7449A, 6.9.2017.

40 On the basis of 161.2 CE. F.J. Pérez, El Constitucional suspende de urgencia la ley del referéndum, “El País”, 8.9.2017: https://politica.elpais.com/politica/2017/09/12/ actualidad/1505202469_540716.html (accessed 4.10.2017).

41 Puigdemont: "Si el Constitucional me inhabilita, no aceptaré esta decisión", "La Vanguardia”, 24.7.2017:

http://www.lavanguardia.com/politica/20170724/4358440154/puigdemont-tribunalconstitucional-inhabilitacion.html (accessed 4.10.2017). 
illegal voting, meanwhile Catalan local police remained passive, and the situation turned into a day-long regional street clash, in which over 800 people were injured ${ }^{42}$. Despite the chaos and numerous irregularities during the vote ${ }^{43}$, the Catalan government announced a success, because over $90 \%$ of votes were cast in favour of independence (with a turnover of just over $42 \%$ of those entitled to vote $)^{44}$. Puigdemont announced that, according to the act on transitional law and the establishment of a republic ${ }^{45}$, adopted on 8 September by the Catalan parliament, and of course immediately suspended by the Spanish Constitutional Court, in the coming days he would proclaim the creation of an independent Republic of Catalonia ${ }^{46}$. In view of Madrid's categorical opposition to starting dialogue on the independence of Catalonia, the head of the Catalan government decided unilaterally to declare independence (unilateral declaración de independencia), which he suspended for several days, irreversibly losing support in the eyes of extreme nationalists and part of Catalan society. However, the independence act had no legal force, but it caused a sharp reaction in the central government. At its request, the Senate pursuant to Article 155 of the Constitution, for the first time in the history of democratic Spain, suspended autonomy, dismissed the current autonomous government, introduced a receivership and called for regional elections on 21 December $2017^{47}$. The former leaders of the autonomous government were arrested or fled abroad.

42 M. Rodríguez, La Generalitat cifra en 844 los atendidos por heridas y ataques de ansiedad, “El País”, 2.10.2017: https://elpais.com/ccaa/2017/10/01/catalunya/1506820036_546150. html (accessed 4.10.2017).

43 There were cases of persons gave submitted than one vote in various polling stations, votes of unauthorized foreigners, and also urns on the streets, left without control, where anyone could vote. Irregularidades en el referéndum: gente que vota cuatro veces, votos 'extranjeros'..., "El Confidencial”, 1.10.2017: https://www.elconfidencial.com/espana/ cataluna/2017-10-01/irregularidades-votaciones-referendum-cataluna_1453255/ (accessed 4.10.2017).

44 See http://www.govern.cat/pres_gov/AppJava/govern/monografics/303483/ resultats-referendum-11-doctubre.html (accessed 4.10.2017).

45 Ley 20/2017, 8.9.2017, de transitoriedad jurídica y fundacional de la República, DOGC, no 7451A, 8.9.2017.

46 D.G. Sastre, Puigdemont proclamará la independencia de Cataluña en dias, "El Mundo", 2.10.2017: http://www.elmundo.es/cataluna/2017/10/01/59d1541a268e3e92668b45d1. html (accessed 4.10.2017).

47 M. Alberola, El Senado aprueba aplicar el artículo 155 en Cataluña, "El País”, 27.10.2017: https://politica.elpais.com/politica/2017/10/27/actualidad/1509105725_777595.html (accessed 27.11.2017). 


\section{Economic crisis as a nationalist propaganda tool}

The economic crisis was not the main cause of the Catalan crisis, but it played an extremely important role on propaganda grounds. The correlation between the economy, an increase in unemployment and the rise of separatist moods in Catalan society was so strong that it created a real basis for nationalists to try to break away from Spain. The temporary disruption of the Catalan government after the 1 October referendum and the massive outflow of companies from Catalonia to other Spanish regions ${ }^{48}$ proved to be decisive for the political future of the autonomous community. The decision of the Catalan government and the delay in the declaration of independence was used by the government of Mariano Rajoy, who adopted a radical attitude suspending the autonomy of the region, but still within the limits of the law set by the Constitution. There were no new laws against this precedent, no violent measures were taken (except for the reckless use of the national enforcement service on the day of the referendum on 1 October), consistently only breaking the separatists' arguments on a legal level. The Catalans, going beyond the political system, have condemned themselves to a weaker position not only in relation to the Madrid government, which is de facto the head of the autonomous governments, but also to entities of international law that did not enter into dialogue with the Catalan government, recommending the resolution of the dispute as an internal matter of Spain. The probable consequences of the Catalan crisis will be a severe economic downturn for the region and the reorganization of political forces, which may marginalize the extreme nationalists.

48 For the first two weeks after the referendum, over 500 companies left Catalonia, including such significant banks as Sabadell and CaixaBank, and Gas Natural, operating in the gas sector. M.V. Gómez, 540 empresas han abandonado Cataluña desde el referendum del 1 de octubre, "El País", 13.10.2017: https://elpais.com/economia/2017/10/13/ actualidad/1507901935_441075.html (accessed 6.12.2017). In total over 3,000 companies left Catalonia after the independence crisis. See Más de 3.000 empresas han llevado su sede fuera de Cataluña desde el referendum, "El País", 13.12.2017:

https://elpais.com/economia/2017/12/13/actualidad/1513180672_824521.html (accessed 15.12.2017). 


\section{Bibliography}

1. Álvaro F.M., Cardús S. (ed.), Claves sobre la independencia de Cataluña, Barcelona 2013

2. Balcells A., Breve historia del nacionalismo catalán, Madrid 2004

3. Bernardos Domínguez G., Creación y destrucción de la burbuja inmobiliaria en España, "Información Comercial Española. Revista de Economía" 2009, no 850

4. Dankowski M.Z., The legality of Catalan independence referendums, "Przegląd Prawa Konstytucyjnego" 2017, no 6

5. Fernández Rincón A.R., Trindade E., Hellín Ortuño P.A., Comprender la burbuja inmobiliaria en España, "Revista Brasileira de Ciências Sociais" 2015, vol 32, no 95

6. Llorens Ferrer M., La consulta popular como mecanismo para revitalizar el urbanisto democrático, "Revista catalana de dret públic" 2013, no 46

7. Martín Núñez E., The referendum and popular consultations in the Autonomous State, "Perspective on Federalism" 2012, vol. 4, no 1

8. Myśliwiec M., Katalonia na drodze do niepodległości?, Bytom 2006

9. Myśliwiec M., Pozycja partii regionalnych w systemie politycznym wspótczesnej Hiszpanii, Katowice 2014

10. Rico G., Liñeira R., Bringing Secessionism into the Mainstream: The 2012 Regional Election in Catalonia, "South European Society and Politics" 2014, vol. 19, no 2

11. Sroka A., Hiszpańska droga do federalizmu, Wrocław 2008

12. Villatoro V., Catalunya després del Tripartit. Una visió nacionalista, Barcelona 2005 